\title{
Critical Harvest Stage Improves Alfalfa Production Performance, Overwintering Rate and Economic Benefits under Drip Irrigation
}

\author{
Xuanshuai Liu ${ }^{\dagger}$, Yanliang Sun ${ }^{\dagger}$, Shengyi Li, Junwei Zhao, Chunhui Ma and Qianbing Zhang* \\ The College of Animal Science \& Technology, Shihezi University, Shihezi, 832003, Xinjiang, China \\ *For correspondence: qbz102@163.com \\ † Contributed equally to this work and are co-first authors \\ Received 17 October 2020; Accepted 12 November 2020; Published 25 January 2021
}

\begin{abstract}
Alfalfa is an important legume forage with high nutritional quality. Harvest stage has an essential impact on alfalfa hay yield and nutritional quality. However, there is no clear indication about the effects of harvest time on the production performance, overwintering rate and economic benefits of alfalfa under drip irrigation. Therefore, this study was conducted to evaluate the impact of harvesting at bud stage $\left(\mathrm{F}_{\mathrm{B}}\right), 5 \%$ flowering stage $\left(\mathrm{F}_{5 \%}\right), 15 \%$ flowering stage $\left(\mathrm{F}_{15 \%}\right)$, and full bloom stage $\left(\mathrm{F}_{50 \%}\right)$ on hay yield and quality, and economic benefits of two alfalfa cultivars i.e., WL354HQ and Magnum551. Harvesting time had significant effect on hay yield of both cultivars $(P \leq 0.05)$ and the order of total dry matter yield $(\mathrm{TDMY}) \mathrm{was} \mathrm{F}_{5 \%}>\mathrm{F}_{15 \%}>$ $\mathrm{F}_{50 \%}>\mathrm{F}_{\mathrm{B}}$. The alfalfa crude protein $(\mathrm{CP})$ content of each cutting in alfalfa decreased gradually with the advance of the harvest stage, while the neutral detergent fiber (NDF) and acid detergent fiber (ADF) contents gradually increased. A comprehensive analysis of alfalfa dry matter yield (DMY), quality and overwintering rate was used to analyze the fuzzy similarity priority ratio, and the priority ranking was as follows: $\mathrm{F}_{\mathrm{B}}>\mathrm{F}_{5 \%}>\mathrm{F}_{15 \%}>\mathrm{F}_{50 \%}$. Maximum economic benefits of both alfalfa cultivars were obtained at $\mathrm{F}_{5 \%}$ harvest time, reaching $2703 \$$ ha $^{-1}$ (WL354HQ) and $2585 \$$ ha $^{-1}$ (Magnum551), followed by $\mathrm{F}_{\mathrm{B}}$, $\mathrm{F}_{15 \%}$, and $\mathrm{F}_{50 \%}$. Therefore, in order to get more hay yield and economic returns, harvesting at $5 \%$ flowering stage of alfalfa seemed viable option under drip irrigation. (c) 2021 Friends Science Publishers
\end{abstract}

Key words: Alfalfa; Harvest stage; Dry matter yield; Nutritional quality; Economic benefits

\section{Introduction}

Alfalfa (Medicago sativa L.), as a kind of excellent legume widely cultivated in the world, is known as the "king of forage" for its high hay yield and nutritional quality ( $\mathrm{Gu}$ et al. 2018; Zhang et al. 2020a). It not only provides a large amount of high-quality forage grass for animal husbandry, but also plays an important role in improving regional economic level (Staniak and Harasim 2018), increasing soil fertility (Jia et al. 2006), preventing soil erosion (Zhao et al. 2004), etc. Xinjiang is an important alfalfa planting area in the northwest of China. It is of great significance to carry out high-quality and efficient alfalfa production under the arid climate of Xinjiang (Zhang et al. 2020b).

The growth and development of alfalfa plants are closely linked to the harvest stage. Alfalfa varies greatly in morphological structure, and physiological and biochemical characteristics at different harvest stages (Lenssen et al. 1990). Additionally, some reports have shown that alfalfa has higher crude protein content and lower crude fiber content at budding stage and early flowering stage than at its full bloom stage, while the forage yield of alfalfa at flowering stage is higher, but the feeding value of alfalfa at flowering stage is lower than that at budding stage and early flowering stage (Lamb et al. 2003; Testa et al. 2011). In the actual production of alfalfa, many factors are affecting the nutrient quality of alfalfa hay, and the harvest time is one of the most important factors (Karayilanli and Ayhan 2016). Alfalfa hay with excellent quality and quantity can be obtained by harvesting it at appropriate period (Yari et al. 2012). However, once the optimal harvest period is missed, the quality of alfalfa will sharply decline, which is mainly manifested as the decrease in crude protein content, the increase in stem-leaf ratio and the contents of crude fibers, and the aging of leaves (Martiniello et al. 1997). Therefore, according to the dynamic changes of hay yield and nutrient quality of alfalfa in different growth periods, it is a key measure to determine the optimal harvest stage to improve the economic benefit of alfalfa production.

Drip irrigation technology is widely used in alfalfa field production due to its advantages of water-saving, high irrigation efficiency, and difficult hardening of soil after irrigation (Trejo et al. 2010). Moreover, the use of drip irrigation technology consumes a series of drip irrigation

To cite this paper: Liu X, Y Sun, S Li, J Zhao, C Ma, Q Zhang (2021). Critical harvest stage improves alfalfa production performance, overwintering rate and economic benefits under drip irrigation. Intl J Agric Biol 25:601-608 
materials, which greatly increase farmers' planting costs. Therefore, how to improve the economic benefit of alfalfa production in arid areas of Xinjiang under the condition of drip irrigation becomes a key problem to be solved in the process of production. At present, in the actual production of drip irrigation alfalfa, the optimal harvest stage of high quality and efficient production of alfalfa is still uncertain owing to the fluctuation of market price, the lack of quality pricing policy and other factors. Consequently, this study was carried out to explore the change characteristics of dry matter yield and nutritional quality of alfalfa, and analyzed the economic benefit of alfalfa at different harvest stages, so that to determine the best harvest stage for the good-quality and high-yield in alfalfa under drip irrigation. We hypothesized that: (1) Harvesting at the early flowering stage of alfalfa will get higher total hay yield and crude protein yield. (2) Overwintering rate of alfalfa will decrease with the increase of cutting frequency. (3) The highest economic benefits of alfalfa may occur at the early flowering stage.

\section{Materials and Methods}

\section{Site description}

The experiment was conducted in the experimental field of agricultural demonstration park at Shihezi Agricultural Research Institute in Shihezi $\left(44^{\circ} 26^{\prime} \mathrm{N}, 85^{\circ} 94^{\prime} \mathrm{E}\right)$, Xinjiang, China, in 2017. The region has a temperate continental climate with a dry climate and a large temperature difference between day and night. The annual average temperature is $10-15^{\circ} \mathrm{C}$, the annual average precipitation is $200-415 \mathrm{~mm}$, the annual evaporation is $1080-1430 \mathrm{~mm}$, the annual sunshine time is $2310-2730 \mathrm{~h}$, and the frost-free period is 147-191 d. The soil type of the test site is gray desert soil with a $\mathrm{pH}$ of 7.65. The physical and chemical properties of $0-20 \mathrm{~cm}$ topsoil in the test site are shown in Table 1.

\section{Experimental details}

Based on the results of the previous pre-test and the results of the experiment conducted in 2017 this field study was conducted to evaluate the impact harvest stages on hay yield, overwintering rate and quality of hay of two alfalfa cultivars. Four growth periods were chosen to determine the hay yield and nutritional quality of alfalfa. The specific harvest periods were as follows: bud stage (50\% of budding, $\left.\mathrm{F}_{\mathrm{B}}\right), 5 \%$ flowering stage $\left(\mathrm{F}_{5 \%}\right), 15 \%$ flowering stage $\left(\mathrm{F}_{15 \%}\right)$, and full bloom stage (50\% flowering, $\left.\mathrm{F}_{50 \%}\right)$. Harvesting according to the above growth periods resulted in 6 cuts in $F_{B}$ stage, 5 cuts in $\mathrm{F}_{5 \%}$ stage, 4 cuts in $\mathrm{F}_{15 \%}$ stage and 3 cuts in $\mathrm{F}_{50 \%}$ stage. The tested alfalfa cultivars WL354HQ and Magnum551 were widely planted in Xinjiang, and the seeds of alfalfa were sown on April 19, 2015. The sowing mode was artificial seeding, with the sowing rate of $18.0 \mathrm{~kg} \mathrm{ha}^{-1}$, the row spacing of alfalfa was $20 \mathrm{~cm}$, and the sowing depth was $1.5-2.0 \mathrm{~cm}$.
The experiment was laid out following randomized complete block design under factorial arrangement with net plot area of $40 \mathrm{~m}^{2}(8 \mathrm{~m} \times 5 \mathrm{~m})$ with three replicates. The harvesting time of alfalfa in different growth periods is given in Table 2 . Other management measures, such as field fertilization $(\mathrm{N}$ : $105 \mathrm{~kg} \mathrm{ha}^{-1}$, P: $\left.100 \mathrm{~kg} \mathrm{ha}^{-1}\right)$ and irrigation $\left(6000 \mathrm{~m}^{3} \mathrm{ha}^{-1}\right)$, were carried out following the local drip-irrigated alfalfa high-yielding fields. All the required irrigation water for each plot was conveyed to each plot through eight inlaid drip irrigation belts with an inner diameter of $12.5 \mathrm{~mm}$ and a working pressure of $0.1 \mathrm{MPa}$. The drip distance of the drip irrigation belt was $20 \mathrm{~cm}$, and the flow rate of the drip irrigation belt was $3.2 \mathrm{~L} \mathrm{~h}^{-1}$. The drip irrigation belt was buried 8-10 cm below the surface at a distance of $60 \mathrm{~cm}$. Drip irrigation belts were laid with three rows of alfalfa in one tube. The concrete irrigation volume was checked by a water meter at the entrance of the plot.

\section{Measurement index and method}

Dry matter yield: The DMY of alfalfa was determined by the sampling method, and the alfalfa plants with the same leaf age were randomly selected. The alfalfa plants (cut to 5 $\mathrm{cm}$ ) in the sampling square were cut with scissors and weighed, and the yield of fresh alfalfa plants was recorded 3 times for each stage; another $300 \mathrm{~g}$ alfalfa plant samples were packed in cloth bags and brought back to the laboratory, dried at $105^{\circ} \mathrm{C}$ for $10 \mathrm{~min}$ in an oven, and then dried at $65^{\circ} \mathrm{C}$ to a constant weight. The moisture content was measured and the alfalfa DMY ( $\left.\mathrm{t} \mathrm{ha}^{-1}\right)$ was calculated. The specific calculation formula is as follows:

$$
\mathrm{DMY}=\mathrm{FGY} \times(1-\mathrm{WC}) \quad(1)
$$

DMY represents dry matter yield of alfalfa, FGY represents fresh grass yield of alfalfa, and WC represents water content of alfalfa.

Nutritional quality: The CP content of alfalfa plants was analyzed by the semi-micro Kjeldahl method (Hirwitz and Latimer 1995), and using the method as described by Van Soest (Soest et al. 1991) to determine the NDF and ADF contents. $\mathrm{CP}$ yield $\left(\mathrm{t} \mathrm{ha}^{-1}\right)$ was calculated by the following formula:

$$
\mathrm{CPY}=\mathrm{CPC} \times \mathrm{DMY}(2)
$$

CPY represents CP yield and CPC represents CP content.

Overwintering rate: After frosting in the experiment area, $1 \mathrm{~m}^{2}(1 \mathrm{~m} \times 1 \mathrm{~m})$ was labeled as a quadrat in the center of the plot on October 14, 2017, and the number of all alfalfa plants in the quadrat was recorded with three replicates. The number of surviving alfalfa plants in the labeled quadrat was then recorded after alfalfa returned to green in 2018 (March $25,2018)$, and the overwintering rate $(\%)$ of alfalfa was calculated using the following equation:

$$
\mathrm{OR}=\mathrm{TN}_{\mathrm{sp}} / \mathrm{TN}_{\mathrm{p}}
$$

OR represents overwintering rate, $\mathrm{TN}_{\mathrm{SP}}$ represents total 
number of surviving plants, and $\mathrm{TN}_{\mathrm{p}}$ represents total number of plants.

Economic benefit: The economic benefit of alfalfa was calculated as the following formula:

$$
\mathrm{EB}=\mathrm{TI}-\mathrm{Ti}
$$

EB $\left(\$ \mathrm{ha}^{-1}\right)$ represents economic benefit, TI represents total income and Ti represents total input. Ti includes material cost (seeds, fertilizer, drip irrigation belts, water and electricity), management fee (sowing, harvesting, drying, bundling, hauling, labor, land lease), etc. The TI was calculated by the following formula:

$$
\mathrm{TI}=\mathrm{TDMY} \times \mathrm{P}_{\mathrm{u}}
$$

TDMY represents Annual total dry matter yield of alfalfa and $\mathrm{P}_{\mathrm{u}}$ represents unit price of alfalfa.

\section{Statistical analysis}

Microsoft Excel 2019 and DPS 7.05 (Data Processing System, China) software were used for statistical analysis. Two-way ANOVA and DMRT (Duncan's multiple range test) were used for the comparison of the differences between different data sets at $P \leq 0.05$. Based on the DMY, CP content, $\mathrm{CP}$ yield, $\mathrm{NDF}, \mathrm{ADF}$ content and overwintering rate of alfalfa, the optimal harvest stage of alfalfa was analyzed using the fuzzy similarity priority ratio method (by DPS 7.05). The fuzzy similarity priority ratio compares many treatments with a fixed optimal one, and a comprehensive ranking result can be obtained. Lower the similarity, better the comprehensive performance. The figures were prepared by Sigma Plot 14.0 (Systat Software Inc., USA).

\section{Results}

\section{Dry matter yield}

The DMY of two alfalfa cultivars WL354HQ and Magnum551 increased gradually with the advancement of the growth period at the same cutting times, and reached the maximum at the $\mathrm{F}_{50 \%}$ (Table 3). The TDMY was the highest $\left(22.68-22.96 \mathrm{t} \mathrm{ha}^{-1}\right)$ when the alfalfa plants were harvested at $\mathrm{F}_{5 \%}$ ( 5 cuts), followed by $\mathrm{F}_{15 \%}$ ( 4 cuts), $\mathrm{F}_{50 \%}$ ( 3 cuts), $\mathrm{F}_{\mathrm{B}}(6$ cuts), and the TDMY of alfalfa increased by $11.0-16.8 \%$ when harvesting at $\mathrm{F}_{5 \%}$ compared with that at $\mathrm{F}_{50 \%}$. The DMY of alfalfa harvested at $\mathrm{F}_{5 \%}-\mathrm{F}_{15 \%}$ was significantly higher than that of alfalfa harvested at $\mathrm{F}_{\mathrm{B}}$ and $\mathrm{F}_{50 \%}(P \leq$ $0.05)$. Except for the first and the fifth cut, the interactions of other cuts in DMY were significantly different $(P \leq 0.05)$. There was significant difference in alfalfa TDMY between cultivars $(P \leq 0.05)$ and among harvest stages $(P \leq 0.01)$, while there was no significant difference in their interaction $(P \geq 0.05)$. Both alfalfa cultivars had the highest DMY in the first crop at different harvest stages. Except for the third crop, the DMY of alfalfa gradually decreased with the increase of cutting times (Table 3 ).

\section{Crude protein}

The CP content of alfalfa in each cut decreased gradually with the advancement of the growth period during the same cutting times. The alfalfa $\mathrm{CP}$ content of each cut was the highest in $\mathrm{F}_{\mathrm{B}}$, while it was the lowest in $\mathrm{F}_{50 \%}$ (Table 4). Harvest stages had a significant effect on alfalfa CP content $(P \leq 0.05)$, while $\mathrm{CP}$ content had no significant respond to the interaction of cultivar and harvest stage. During the same growth period, CP content in alfalfa showed a slight decline with the increase of cutting numbers. Compared with the first crop, the $\mathrm{CP}$ content of the last crop in each growth period was reduced by a greater degree, ranging from 0.47 to $3.51 \%$. And two alfalfa cultivars WL354HQ and Magnum551 showed the same rule.

To further clarify the effect of harvesting at different growth periods on alfalfa $\mathrm{CP}$ yield, the $\mathrm{CP}$ yield was calculated by converting alfalfa DMY and CP content. The results showed that harvest stages had a significant effect on $\mathrm{CP}$ yield in all cuts of alfalfa $(P \leq 0.05)$ (Table 5). There was no significant difference between two cultivars in total CP yield of alfalfa $(P \geq 0.05)$, while harvest stage had a significant effect on alfalfa total $\mathrm{CP}$ yield $(P \leq 0.05)$. However, there was also no significant difference in their interaction $(P \geq 0.05)$. According to the total $\mathrm{CP}$ yield of each crop in different growth periods, harvesting at $\mathrm{F}_{5 \%}$ had the highest total CP yield, with 3.97 and $3.90 \mathrm{t} \mathrm{ha}^{-1} \mathrm{CP}$ yield of cultivar WL354HQ and Magnum551 respectively, followed by $\mathrm{F}_{\mathrm{B}}$ and $\mathrm{F}_{15 \%}$. Compared with $\mathrm{F}_{5 \%}$, the total $\mathrm{CP}$ yield of the alfalfa cultivar WL354HQ at $\mathrm{F}_{50 \%}$ was decreased by $27.85 \%$, and Magnum551 decreased by 25.24\%.

\section{Neutral and acid detergent fiber}

There were significant differences with NDF content (Table 6) and ADF content (Table 7) with change in harvest stages $(P \leq 0.01)$, while there was no statistically significant difference in cultivars and their interactions with harvest stages $(P \geq 0.05)$. The contents of NDF and ADF of alfalfa were both the lowest in $\mathrm{F}_{\mathrm{B}}$, followed by $\mathrm{F}_{5 \%}, \mathrm{~F}_{15 \%}$ and $\mathrm{F}_{50 \%}$. The NDF contents of WL354HQ and Magnum551 during $\mathrm{F}_{\mathrm{B}}$ decreased by $37.8-43.2 \%$ and $29.6-35.1 \%$ respectively compared with those of full bloom stage, and the contents of ADF were $43.6-54.4 \%$ and 30.9-40.3\% lower than that of $\mathrm{F}_{50 \%}$, respectively. The NDF and ADF contents of alfalfa both increased firstly and then decreased with the increase of cutting times during the same growth period (the NDF contents during $\mathrm{F}_{50 \%}$ and $\mathrm{F}_{15 \%}$ only showed a gradual increasing trend because only 3 and 4 crops of alfalfa were cut respectively), and the maximum value was concentrated in the third or fourth stubble. The changes of NDF and ADF contents in the two cultivars were the same.

\section{Overwintering rate}

With the advancing of the growth period, the overwintering 
Liu et al. / Intl J Agric Biol, Vol 25, No 3, 2021

Table 1: Physicochemical properties of 0-20 $\mathrm{cm}$ soil in the experiment

\begin{tabular}{llllllll}
\hline $\begin{array}{l}\text { Total nitrogen } \\
\left(\mathrm{g} \mathrm{kg}^{-1}\right)\end{array}$ & $\begin{array}{l}\text { Available nitrogen } \\
\left(\mathrm{mg} \mathrm{kg}^{-1}\right)\end{array}$ & $\begin{array}{l}\text { Total phosphorus } \\
\left(\mathrm{g} \mathrm{kg}^{-1}\right)\end{array}$ & $\begin{array}{l}\text { Available Phosphorus } \\
\left(\mathrm{mg} \mathrm{kg}^{-1}\right)\end{array}$ & $\begin{array}{l}\text { Available Potassium } \\
\left(\mathrm{mg} \mathrm{kg}^{-1}\right)\end{array}$ & $\begin{array}{l}\text { Organic matter } \\
\left(\mathrm{g} \mathrm{kg}^{-1}\right)\end{array}$ & $\begin{array}{l}\text { Soil bulk density } \\
\left(\mathrm{g} \mathrm{cm}^{-1}\right)\end{array}$ & $\begin{array}{l}\text { Field capacity } \\
(\%)\end{array}$ \\
\hline 1.63 & 72.5 & 0.19 & 15.2 & 139.6 & 25.3 & 1.46 & 24.6 \\
\hline
\end{tabular}

Table 2: Harvesting time of each cut at different harvest stages (Month-Day) (2017)

\begin{tabular}{llllll}
\hline Harvest stage & First cut & Second cut & Third cut & Fourth cut & Sixth cut \\
\hline $\mathrm{F}_{\mathrm{B}}$ & $05-04$ & $06-03$ & $07-01$ & $07-25$ & $08-18$ \\
$\mathrm{~F}_{5 \%}$ & $05-12$ & $06-15$ & $07-16$ & $08-19$ & $09-20$ \\
$\mathrm{~F}_{15 \%}$ & $05-25$ & $06-28$ & $08-05$ & $09-15$ & - \\
$\mathrm{F}_{50 \%}$ & $06-10$ & $07-30$ & $09-18$ & - & - \\
\hline $\mathrm{F}_{\mathrm{B}}$ bud stage; $\mathrm{F}_{5 \%}$ 5\% flowering & - & & -
\end{tabular}

$\mathrm{F}_{\mathrm{B}}$, bud stage; $\mathrm{F}_{5 \%}, 5 \%$ flowering stage; $\mathrm{F}_{15 \%}, 15 \%$ flowering stage; $\mathrm{F}_{50 \%}$, full bloom stage

Table 3: Effect of harvest stage on dry matter yield $\left(\mathrm{tha}^{-1}\right)$ of two alfalfa cultivars

\begin{tabular}{|c|c|c|c|c|c|c|c|c|}
\hline Cultivars & Harvest stage & First cut & Second cut & Third cut & Fourth cut & Fifth cut & Sixth cut & TDMY \\
\hline \multirow[t]{4}{*}{ WL354HQ } & $\mathrm{F}_{\mathrm{B}}$ & $4.81 \pm 0.17 d$ & $3.19 \pm 0.14 d$ & $4.19 \pm 0.14 d$ & $3.01 \pm 0.16 c$ & $2.48 \pm 0.13$ & $1.52 \pm 0.16$ & $19.20 \pm 0.31 c$ \\
\hline & $\mathrm{F}_{5 \%}$ & $5.96 \pm 0.18 c$ & $4.78 \pm 0.17 c$ & $5.20 \pm 0.16 c$ & $4.47 \pm 0.17 b$ & $2.55 \pm 0.16$ & - & $22.96 \pm 0.34 a$ \\
\hline & $\mathrm{F}_{15 \%}$ & $6.65 \pm 0.19 b$ & $5.14 \pm 0.18 b$ & $5.48 \pm 0.17 b$ & $4.73 \pm 0.19 a$ & - & - & $22.01 \pm 0.29 b$ \\
\hline & $\mathrm{F}_{50 \%}$ & $7.47 \pm 0.25 a$ & $6.23 \pm 0.24 a$ & $5.95 \pm 0.24 a$ & - & - & - & $19.64 \pm 0.21 \mathrm{c}$ \\
\hline \multirow[t]{4}{*}{ Magnum551 } & $\mathrm{F}_{\mathrm{B}}$ & $4.88 \pm 0.17 d$ & $3.44 \pm 0.16 \mathrm{~d}$ & $4.42 \pm 0.19 \mathrm{~d}$ & $3.07 \pm 0.18 c$ & $2.32 \pm 0.17$ & $1.58 \pm 0.15$ & $19.71 \pm 0.42 c$ \\
\hline & $\mathrm{F}_{5 \%}$ & $6.00 \pm 0.26 c$ & $5.21 \pm 0.19 c$ & $4.76 \pm 0.16 c$ & $4.29 \pm 0.15 b$ & $2.42 \pm 0.18$ & - & $22.68 \pm 0.32 \mathrm{a}$ \\
\hline & $\mathrm{F}_{15 \%}$ & $6.80 \pm 0.19 b$ & $5.48 \pm 0.22 b$ & $5.47 \pm 0.23 b$ & $4.47 \pm 0.16 \mathrm{a}$ & - & - & $22.23 \pm 0.28 \mathrm{a}$ \\
\hline & $\mathrm{F}_{50 \%}$ & $7.60 \pm 0.20 \mathrm{a}$ & $7.16 \pm 0.18 \mathrm{a}$ & $5.66 \pm 0.19 a$ & - & - & - & $20.43 \pm 0.27 b$ \\
\hline Cultivar & & $* *$ & $* *$ & $* *$ & $* *$ & $* *$ & ns & $*$ \\
\hline Harvest stage & & $* *$ & $* *$ & $* *$ & $* *$ & ns & - & $* *$ \\
\hline Interaction & & $\mathrm{ns}$ & $* *$ & $* *$ & $* *$ & ns & - & ns \\
\hline
\end{tabular}

Table 4: Effect of harvest stage on crude protein contents (\%) of two alfalfa cultivars

\begin{tabular}{|c|c|c|c|c|c|c|c|}
\hline Cultivar & Harvest stage & First cut & Second cut & Third cut & Fourth cut & Fifth cut & Sixth cut \\
\hline \multirow[t]{4}{*}{ WL354HQ } & $\mathrm{F}_{\mathrm{B}}$ & $21.19 \pm 0.49 \mathrm{a}$ & $20.54 \pm 0.52 \mathrm{a}$ & $20.08 \pm 0.48 a$ & $19.78 \pm 0.50 \mathrm{a}$ & $19.07 \pm 0.56 \mathrm{a}$ & $18.33 \pm 0.54$ \\
\hline & $\mathrm{F}_{5 \%}$ & $18.20 \pm 0.58 b$ & $17.68 \pm 0.48 b$ & $17.38 \pm 0.52 b$ & $16.53 \pm 0.53 b$ & $15.73 \pm 0.55 b$ & - \\
\hline & $\mathrm{F}_{15 \%}$ & $17.01 \pm 0.60 \mathrm{c}$ & $16.70 \pm 0.54 c$ & $16.10 \pm 0.41 c$ & $15.18 \pm 0.48 c$ & - & - \\
\hline & $\mathrm{F}_{50 \%}$ & $15.11 \pm 0.58 \mathrm{~d}$ & $14.43 \pm 0.58 \mathrm{~d}$ & $14.20 \pm 0.56 \mathrm{~d}$ & - & - & - \\
\hline \multirow[t]{4}{*}{ Magnum551 } & $\mathrm{F}_{\mathrm{B}}$ & $20.47 \pm 0.50 \mathrm{a}$ & $19.61 \pm 0.39 a$ & $18.87 \pm 0.50 \mathrm{a}$ & $18.95 \pm 0.51 \mathrm{a}$ & $18.92 \pm 0.54 \mathrm{a}$ & $18.63 \pm 0.46$ \\
\hline & $\mathrm{F}_{5 \%}$ & $17.87 \pm 0.48 b$ & $17.41 \pm 0.49 b$ & $16.98 \pm 0.52 b$ & $17.15 \pm 0.43 b$ & $16.60 \pm 0.49 b$ & - \\
\hline & $\mathrm{F}_{15 \%}$ & $16.55 \pm 0.52 c$ & $15.65 \pm 0.46 c$ & $15.47 \pm 0.45 c$ & $15.09 \pm 0.44 c$ & - & - \\
\hline & $\mathrm{F}_{50 \%}$ & $14.67 \pm 0.48 \mathrm{~d}$ & $14.17 \pm 0.49 \mathrm{~d}$ & $13.67 \pm 0.48 \mathrm{~d}$ & - & - & - \\
\hline Cultivar & & $*$ & $* *$ & $* *$ & ns & ns & ns \\
\hline Harvest stage & & $* *$ & $* *$ & $* *$ & $* *$ & $* *$ & - \\
\hline Interaction & & ns & ns & ns & ns & ns & - \\
\hline
\end{tabular}

rates of alfalfa WL354HQ and Magnum551 increased gradually and reached the highest in the $\mathrm{F}_{50 \%}$ (cutting 3 crops). However, there was no significant difference with the overwintering rates of alfalfa between $\mathrm{F}_{5 \%}$ and $\mathrm{F}_{15 \%}(P \geq$ $0.05)$, and the overwintering rates of alfalfa in $\mathrm{F}_{5 \%}, \mathrm{~F}_{15 \%}$ and $\mathrm{F}_{50 \%}$ were significantly greater than those in $\mathrm{F}_{\mathrm{B}}(P \leq 0.05)$ (Fig. 1). The overwintering rate of alfalfa reduced significantly when cutting 6 times. The interaction of cultivar and harvest stage had no significant influence on overwintering rate of alfalfa $(P \geq 0.05)$ (Fig. 1).

\section{Fuzzy similarity priority ratio analysis}

To determine the optimal harvest stage of drip irrigation alfalfa more accurately, this study analyzed the alfalfa DMY, $\mathrm{CP}$ content, $\mathrm{CP}$ yield, NDF content, ADF content and wintering rate by fuzzy similarity priority ratio analysis (Table 8). The results showed that cultivars WL354HQ and Magnum 551 were both ranked first in the harvest stage of $\mathrm{F}_{\mathrm{B}}$, followed by $\mathrm{F}_{5 \%}, \mathrm{~F}_{15 \%}$ and $\mathrm{F}_{50 \%}$, but the similarity of $\mathrm{F}_{5 \%}$ and $F_{B}$ was extremely close. We inferred that the stage of $F_{B}$ or $\mathrm{F}_{5 \%}$ may be more suitable for harvesting.

\section{Economic benefits}

In the actual production of alfalfa, the optimal harvesting period should be determined in combination with the production cost to achieve the maximum economic benefits. The results of economic benefit analysis showed that (Table 9) the maximum economic benefit could be obtained by harvesting at $\mathrm{F}_{5 \%}$, and the net profit reached 2585.09$2703.13 \$ \mathrm{ha}^{-1}$, followed by the $\mathrm{F}_{\mathrm{B}}, \mathrm{F}_{15 \%}$ and $\mathrm{F}_{50 \%}$. And the 
Impact of Harvest Stage on Hay Yield and Quality of Alfalfa / Intl J Agric Biol, Vol 25, No 3, 2021

Table 5: Effect of harvest stage on crude protein yield $\left(\mathrm{t} \mathrm{ha}^{-1}\right)$ of two alfalfa cultivars

\begin{tabular}{lllllllll}
\hline Cultivars & Harvest stage & First cut & Second cut & Third cut & Fourth cut & Fifth cut & Sixth cut & Total crude protein yield \\
\hline WL354HQ & $\mathrm{F}_{\mathrm{B}}$ & $0.99 \pm 0.03 \mathrm{~b}$ & $0.66 \pm 0.02 \mathrm{~b}$ & $0.81 \pm 0.04 \mathrm{~b}$ & $0.59 \pm 0.02 \mathrm{~b}$ & $0.48 \pm 0.01 \mathrm{a}$ & $0.28 \pm 0.01$ & $3.81 \pm 0.15 \mathrm{ab}$ \\
& $\mathrm{F}_{5 \%}$ & $1.08 \pm 0.04 \mathrm{a}$ & $0.85 \pm 0.04 \mathrm{a}$ & $0.90 \pm 0.03 \mathrm{a}$ & $0.74 \pm 0.03 \mathrm{a}$ & $0.41 \pm 0.01 \mathrm{~b}$ & - & $3.97 \pm 0.16 \mathrm{a}$ \\
& $\mathrm{F}_{15 \%}$ & $1.14 \pm 0.04 \mathrm{a}$ & $0.86 \pm 0.03 \mathrm{a}$ & $0.88 \pm 0.03 \mathrm{a}$ & $0.74 \pm 0.04 \mathrm{a}$ & - & - & $3.61 \pm 0.14 \mathrm{~b}$ \\
& $\mathrm{~F}_{50 \%}$ & $1.11 \pm 0.04 \mathrm{a}$ & $0.90 \pm 0.04 \mathrm{a}$ & $0.86 \pm 0.04 \mathrm{ab}$ & - & - & - & $2.86 \pm 0.09 \mathrm{c}$ \\
Magnum551 & $\mathrm{F}_{\mathrm{B}}$ & $0.98 \pm 0.03 \mathrm{~b}$ & $0.67 \pm 0.02 \mathrm{c}$ & $0.84 \pm 0.03 \mathrm{a}$ & $0.58 \pm 0.02 \mathrm{~b}$ & $0.45 \pm 0.02 \mathrm{a}$ & $0.30 \pm 0.02$ & $3.82 \pm 0.17 \mathrm{a}$ \\
& $\mathrm{F}_{5 \%}$ & $1.06 \pm 0.04 \mathrm{a}$ & $0.91 \pm 0.04 \mathrm{~b}$ & $0.81 \pm 0.04 \mathrm{ab}$ & $0.72 \pm 0.03 \mathrm{a}$ & $0.39 \pm 0.02 \mathrm{~b}$ & - & $3.90 \pm 0.12 \mathrm{a}$ \\
& $\mathrm{F}_{15 \%}$ & $1.12 \pm 0.05 \mathrm{a}$ & $0.88 \pm 0.04 \mathrm{~b}$ & $0.85 \pm 0.04 \mathrm{a}$ & $0.69 \pm 0.03 \mathrm{a}$ & - & - & $3.54 \pm 0.15 \mathrm{~b}$ \\
& $\mathrm{~F}_{50 \%}$ & $1.12 \pm 0.05 \mathrm{a}$ & $1.02 \pm 0.04 \mathrm{a}$ & $0.77 \pm 0.03 \mathrm{~b}$ & - & - & - & $2.91 \pm 0.09 \mathrm{c}$ \\
Cultivar & $\mathrm{ns}$ & $* *$ & $* *$ & $*$ & $\mathrm{~ns}$ & $\mathrm{~ns}$ & $\mathrm{~ns}$ \\
Harvest stage & & $* *$ & $* *$ & $*$ & $* *$ & $* *$ & - & $* *$ \\
Interaction & & $\mathrm{ns}$ & $\mathrm{ns}$ & $*$ & $\mathrm{~ns}$ & $\mathrm{~ns}$ & - & $\mathrm{ns}$ \\
\hline The different lowercase letters in the same column indicate significant differences among harvest stage levels under the same cultivar $(P \leq 0.05)$ & \\
**= Significant at $P \leq 0.01 ; *=$ Significant at $P \leq 0.05 ;$ ns= Non-significant; FB, bud stage; F5\%, $5 \%$ flowering stage; F15\%, 15\% flowering stage; F50\%, full bloom stage
\end{tabular}

Table 6: Effect of harvest stage on neutral detergent fiber contents (\%) of two alfalfa cultivars

\begin{tabular}{|c|c|c|c|c|c|c|c|}
\hline Cultivar & Harvest stage & First cut & Second cut & Third cut & Fourth cut & Fifth cut & Sixth cut \\
\hline \multirow[t]{4}{*}{ WL354HQ } & $\mathrm{F}_{\mathrm{B}}$ & $28.81 \pm 1.36 c$ & $30.71 \pm 1.23 \mathrm{c}$ & $33.31 \pm 1.14 c$ & $35.09 \pm 1.37 \mathrm{~b}$ & $32.99 \pm 1.10 b$ & $31.06 \pm 1.34$ \\
\hline & $\mathrm{F}_{5 \%}$ & $34.67 \pm 1.26 b$ & $36.35 \pm 1.15 b$ & $38.13 \pm 1.68 b$ & $40.53 \pm 1.49 \mathrm{a}$ & $37.96 \pm 1.47 \mathrm{a}$ & - \\
\hline & $\mathrm{F}_{15 \%}$ & $37.31 \pm 1.46 b$ & $38.00 \pm 1.56 b$ & $40.52 \pm 1.43 b$ & $43.05 \pm 2.00 \mathrm{a}$ & - & - \\
\hline & $\mathrm{F}_{50 \%}$ & $40.83 \pm 1.81 \mathrm{a}$ & $43.98 \pm 1.92 \mathrm{a}$ & $45.81 \pm 1.76 \mathrm{a}$ & - & - & - \\
\hline \multirow[t]{4}{*}{ Magnum551 } & $\mathrm{F}_{\mathrm{B}}$ & $29.63 \pm 1.29 c$ & $32.14 \pm 0.94 c$ & $33.78 \pm 1.01 \mathrm{c}$ & $34.05 \pm 1.30 \mathrm{c}$ & $31.62 \pm 1.20 \mathrm{~b}$ & $29.58 \pm 0.77$ \\
\hline & $\mathrm{F}_{5 \%}$ & $34.79 \pm 1.52 b$ & $37.53 \pm 1.35 b$ & $39.83 \pm 1.67 b$ & $38.90 \pm 1.55 b$ & $35.78 \pm 1.66 a$ & - \\
\hline & $\mathrm{F}_{15 \%}$ & $37.50 \pm 1.71 \mathrm{a}$ & $39.04 \pm 1.36 b$ & $42.19 \pm 2.18 b$ & $43.17 \pm 1.90 \mathrm{a}$ & - & - \\
\hline & $\mathrm{F}_{50 \%}$ & $39.92 \pm 1.78 \mathrm{a}$ & $41.66 \pm 1.12 \mathrm{a}$ & $45.63 \pm 1.95 \mathrm{a}$ & - & - & - \\
\hline Cultivar & & ns & ns & ns & ns & ns & ns \\
\hline Harvest stage & & $* *$ & $* *$ & $* *$ & $* *$ & $* *$ & - \\
\hline Interaction & & ns & ns & ns & ns & ns & - \\
\hline
\end{tabular}

Table 7: Effect of harvest stage on acid detergent fiber contents (\%) of two alfalfa cultivars

\begin{tabular}{|c|c|c|c|c|c|c|c|}
\hline Cultivar & Harvest stage & First cut & Second cut & Third cut & Fourth cut & Fifth cut & Sixth cut \\
\hline \multirow[t]{4}{*}{ WL354HQ } & $F_{B}$ & $22.39 \pm 0.86 c$ & $23.65 \pm 0.78 c$ & $24.85 \pm 1.43 c$ & $25.69 \pm 1.33 c$ & $23.81 \pm 1.01 \mathrm{~b}$ & $22.30 \pm 0.89$ \\
\hline & $\mathrm{F}_{5 \%}$ & $27.14 \pm 1.79 b$ & $29.46 \pm 1.38 b$ & $30.61 \pm 1.56 b$ & $30.29 \pm 0.78 b$ & $29.06 \pm 1.60 \mathrm{a}$ & - \\
\hline & $\mathrm{F}_{15 \%}$ & $28.85 \pm 1.29 b$ & $30.85 \pm 1.53 b$ & $31.68 \pm 0.90 b$ & $33.17 \pm 1.86 \mathrm{a}$ & - & - \\
\hline & $\mathrm{F}_{50 \%}$ & $32.17 \pm 1.73 \mathrm{a}$ & $36.52 \pm 1.54 \mathrm{a}$ & $36.48 \pm 2.06 \mathrm{a}$ & - & - & - \\
\hline \multirow[t]{4}{*}{ Magnum551 } & $\mathrm{F}_{\mathrm{B}}$ & $22.95 \pm 0.94 c$ & $24.82 \pm 1.06 \mathrm{~d}$ & $26.85 \pm 1.18 \mathrm{c}$ & $25.74 \pm 1.25 b$ & $23.45 \pm 0.80 b$ & $21.60 \pm 0.85$ \\
\hline & $\mathrm{F}_{5 \%}$ & $27.44 \pm 1.10 b$ & $28.95 \pm 1.50 \mathrm{c}$ & $30.44 \pm 1.49 b$ & $27.53 \pm 0.87 b$ & $26.74 \pm 1.07 \mathrm{a}$ & - \\
\hline & $\mathrm{F}_{15 \%}$ & $29.14 \pm 1.04 b$ & $31.93 \pm 1.57 b$ & $32.66 \pm 0.99 \mathrm{ab}$ & $32.64 \pm 1.14 \mathrm{a}$ & - & - \\
\hline & $\mathrm{F}_{50 \%}$ & $32.21 \pm 0.92 \mathrm{a}$ & $34.55 \pm 1.34 \mathrm{a}$ & $35.15 \pm 1.66 \mathrm{a}$ & - & - & - \\
\hline Cultivar & & ns & ns & ns & ns & ns & ns \\
\hline Harvest stage & & $* *$ & $* *$ & $* *$ & $* *$ & $* *$ & - \\
\hline Interaction & & ns & ns & ns & Ns & ns & - \\
\hline
\end{tabular}

economic benefits of $\mathrm{F}_{5 \%}, \mathrm{~F}_{\mathrm{B}}$, and $\mathrm{F}_{15 \%}$ dramatically higher than that in the $\mathrm{F}_{50 \%}$. Among them, the profit of alfalfa harvesting at $\mathrm{F}_{5 \%}$ was $69.9-72.5 \%$ higher than that at the $\mathrm{F}_{50 \%}$ (Table 9).

\section{Discussion}

Dry matter yield of alfalfa is an important indicator to measure the production performance of alfalfa, so it can be utilized to directly characterize the economic benefits of alfalfa production when little difference in nutritional quality exists (Rade et al. 2012). Dry matter yield of alfalfa is influenced by many factors, such as the variety of alfalfa, fertilization, field management mode, and harvest stage, which all have a strong relationship with the dry matter yield of alfalfa (Dhont et al. 2004). While harvesting time is an influential factor that is relatively easy to control (Lamb et al. 2003). Studies have shown that alfalfa forage yield varies significantly at different harvest stages (Moyer et al. 1999). The current study found that as the growth period progressed, the DMY of alfalfa showed a gradual upward trend and reached the maximum at the $\mathrm{F}_{\mathrm{B}}$, which was mainly because the DMY of alfalfa was closely related to the plant height, stem diameter, stem-leaf ratio of alfalfa plants (Annicchiarico 1993). With the advancing of the growth period, alfalfa showed the basic growth rule of "slow-fast-slow", which broadly conformed to the "S" growth curve of plants. During the period from the bud 
Table 8: Fuzzy similarity priority ratio analysis

\begin{tabular}{|c|c|c|c|}
\hline Cultivar & Harvest stage & Similarity & Sorting \\
\hline \multirow{4}{*}{ WL354HQ } & $F_{B}$ & 16 & 1 \\
\hline & $\mathrm{F}_{5 \%}$ & 17 & 2 \\
\hline & $\mathrm{F}_{15 \%}$ & 25 & 3 \\
\hline & $\mathrm{F}_{50 \%}$ & 32 & 4 \\
\hline \multirow[t]{4}{*}{ Magnum551 } & $\mathrm{F}_{\mathrm{B}}$ & 16 & 1 \\
\hline & $\mathrm{F}_{5 \%}$ & 17 & 2 \\
\hline & $\mathrm{F}_{15 \%}$ & 25 & 3 \\
\hline & $\mathrm{F}_{50 \%}$ & 32 & 4 \\
\hline
\end{tabular}

FB, bud stage; F5\%, 5\% flowering stage; F15\%, 15\% flowering stage; F50\%, full bloom stage

Table 9: Economic benefit $\left(\$ \mathrm{ha}^{-1}\right)$ of alfalfa harvested at different harvest stages

\begin{tabular}{lllll}
\hline Cultivar & Harvest stage & Earnings & Cost & Profit \\
\hline WL354HQ & $\mathrm{F}_{\mathrm{B}}$ & 5344.50 & 2859.24 & 2485.26 \\
& $\mathrm{~F}_{5 \%}$ & 5384.64 & 2681.51 & 2703.13 \\
& $\mathrm{~F}_{15 \%}$ & 4914.54 & 2503.78 & 2410.76 \\
Magnum551 & $\mathrm{F}_{50 \%}$ & 3892.89 & 2326.05 & 1566.84 \\
& $\mathrm{~F}_{\mathrm{B}}$ & 5129.89 & 2859.24 & 2267.69 \\
& $\mathrm{~F}_{5 \%}$ & 5266.60 & 2681.51 & 2585.09 \\
& $\mathrm{~F}_{15 \%}$ & 4707.19 & 2503.78 & 2203.41 \\
& $\mathrm{~F}_{50 \%}$ & 3847.57 & 2326.05 & 1521.52 \\
\hline
\end{tabular}

FB, bud stage; F5\%, 5\% flowering stage; F15\%, 15\% flowering stage; F50\%, full bloom stage

Note: Alfalfa hay is priced at $0.237 \$$ per kg containing $17 \%$ crude protein (calculated based on the 2017 local market price and the 2017 average exchange rate of RMB USD, $1 \$=$ $6.7518 \mathrm{CNY}$ ), each increase or decrease of $1 \%$ crude protein content, the price increases or decreases by $0.0148 \$$ accordingly

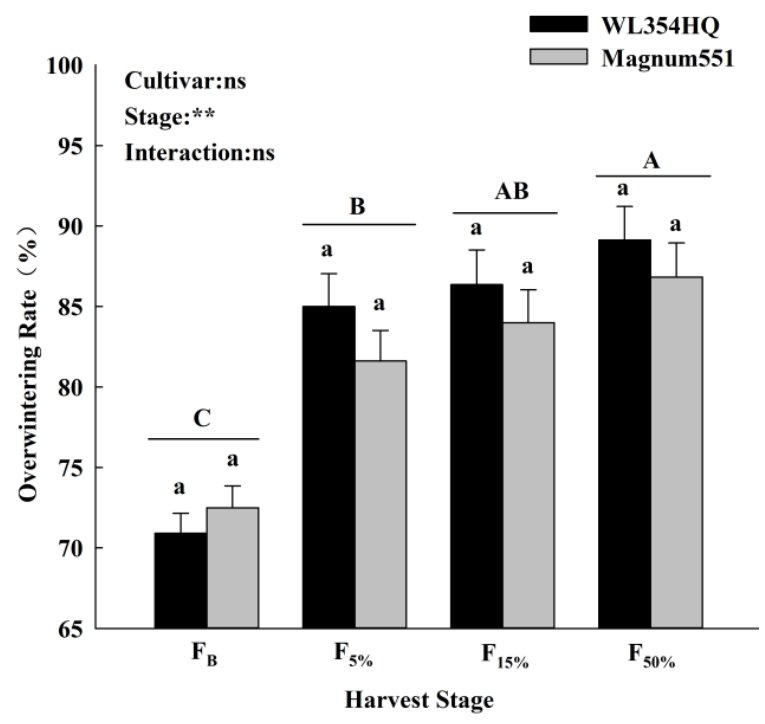

Fig. 1: Overwintering rate of alfalfa harvested at different harvest stages

The same lower case letters on the bars show there is no significant differences between WL354HQ and Magnum551 treatments at $P \leq 0.05$ and bars with different capital letters show there is significant differences among harvest stages at $P \leq 0.05$

$\mathrm{ns}=$ Non-significant; $\mathrm{F}_{\mathrm{B}=}$ Bud stage; $\mathrm{F}_{5 \%}=5 \%$ flowering stage; $\mathrm{F}_{15 \%}=15 \%$ flowering stage; $\mathrm{F}_{50 \%}=$ Full bloom stage

stage to the early flowering stage, as a fast-growing leguminous plant, the photosynthetic capacity of alfalfa increased rapidly, so the yield gradually increased. However, the growth rate of alfalfa plants slowed down after growing into the full bloom stage and the DMY increased slightly or unchanged due to the growth rhythm.

In this study, with the increase of harvest times, the DMY of alfalfa showed a slowly decrease during the same growth period. This result may be explained by the fact that alfalfa has accumulated lots of nutrients during a long winter, and there are enough nutrients to promote alfalfa plants to grow rapidly after the arrival of spring. As for the yield of the last crop corresponding to each growth period was the lowest, a possible explanation for this might be that alfalfa consumes many nutrients in the soil after the first few harvests, resulting in a decrease in the growth of subsequent alfalfa plants (Ventroni et al. 2010). Another possible explanation for this is that the last harvest is in autumn, which is lower air temperature and shorter duration of light, thus causing a weaker photosynthetic capacity and a slower 
growth rate of alfalfa. The results of a 2-year alfalfa planting experiments conducted in Argentina at cutting intervals of 40, 30 and 20 days respectively showed that the annual total hay yield of alfalfa decreased gradually with the increase of cutting frequency (Ventroni et al. 2010), and the same results were also demonstrated in experiments implemented in Kansas, central United States (Min 2016). The results of this study supported those of the previous.

Crude protein, NDF and ADF are important indicators for evaluating the nutritional quality of alfalfa forage (Avci et al. 2017). The study showed that the content of CP and carotene in alfalfa decreased, but the content of NDF and ADF increased gradually with the development of growth period (Albrecht et al. 1987). The nutritional quality of alfalfa hay in different growth periods was best at the bud stage, followed by the initial flowering stage, full flowering stage and pod stage (Albrecht et al. 1987). A 4-yr continuous trial conducted in hilly areas of southern Italy concluded that early harvesting resulted in lower forage yield and shorter forage life, but higher quality characteristics such as $\mathrm{CP}, \mathrm{NDF}$ and ADF (Testa et al. 2011). The results of our study were similar to the results of previous researches. Studies have revealed that the protein in alfalfa plants mainly exists in the chloroplast, and as alfalfa reaches the flowering stage, the physiological function of alfalfa matures, the growth mode of alfalfa gradually transforms from vegetative growth to reproductive growth, and the nutrients in plants are more focused on ensuring flowering and subsequent fruiting processes (Lamb et al. 2012), the nutrients used for plant growth will be insufficient. This transformation process makes alfalfa more lignified, which in turn leads to the decrease of $\mathrm{CP}$ content and the increase of NDF and ADF content.

At the same time, changes in the content of certain small molecule metabolites during the growth process of plants can also cause significant changes in their nutritional value. Studies have illuminated that the contents of carotene, lysine, methionine, arginine and tryptophan decreased to different degrees after alfalfa grew to the full budding stage (Han 2007). Also, with the advancement of the growth period, L-glutamic acid, as an important intermediate product in the synthesis of plant proteins, is gradually reduced, and the contents of purine, pyrimidine and other small molecular substances constituting non-protein nitrogen in plants are gradually reduced (Semel et al. 2007; Fan et al. 2018), which in turn causes the decrease of crude protein content in alfalfa plants. Besides, the expression of L-phenylalanine, salicylic acid and D-mannose, which are closely related to the synthesis of alfalfa lignin and hemicellulose, is up-regulated with the advancing growth period, and is also a crucial reason for the elevation of NDF content and ADF content of alfalfa (Fan et al. 2018).

The overwintering rate has a vital effect on the yield of alfalfa plants in the second year. There are many factors affecting the overwintering rate, such as fall dormancy, cold resistance index, climatic conditions, cutting times, etc.
Studies have shown that the overwintering rate of alfalfa shows a slightly decreasing trend with the increase of cutting times (Sheaffer et al. 1992), because frequent cutting can reduce the regeneration ability of alfalfa (Ventroni et al. 2010). Meanwhile, the earlier the harvest stage, the more the cutting times, the greater the nutrient consumption of alfalfa plant roots, and then the more serious damage to alfalfa plants. Kallenbach et al. (2002) revealed that high harvesting frequency may reduce the resistance of alfalfa plants, which was not conducive to the safe overwintering of alfalfa plants, ultimately leading to the decline of dry matter yield and nutritional quality of alfalfa in the next year. It is also believed that frequent cutting will sharply decrease the hay yield of alfalfa in the coming year (Gramshaw et al. 1993), and the results of this study are in agreement with previous results. However, the difference between the two is that the decline of alfalfa hay yield is different in magnitude; this is because the alfalfa varieties used by the two have different fall dormancy, which affects the wintering rate of the two, resulting in an inconsistent decline in the alfalfa hay production next year.

Harvest time is one of the main factors determining the quantitative and quality traits of alfalfa. Early harvest has low yield, high protein content and high digestibility, while there is high yield, low protein content and low digestibility in late harvest. Therefore, both yield and quality of alfalfa must be taken into consideration in the realistic production of alfalfa. Prior studies have proposed that harvesting at 30-35 d cutting intervals maximizes both dry matter yield and nutrient quality of alfalfa (Hoveland et al. 1996). In this study, the comprehensive performance of alfalfa was the best at the bud stage and 5\% flowering stage. However, a series of input costs in actual production such as seed, drip irrigation belt, water and electricity fee, land lease, harvest fee and field management should be considered comprehensively to determine the optimal harvest stage of alfalfa and further achieve the highest economic benefits. Our hypothesis that the highest economic benefits of alfalfa may occur at the early flowering stage was mostly upheld judging from dry matter yield, nutritional quality, overwintering rate and economic benefits of alfalfa.

\section{Conclusion}

The TDMY and CP yield of alfalfa were the highest when harvesting at $\mathrm{F}_{5 \%}$, followed by $\mathrm{F}_{15 \%}, \mathrm{~F}_{50 \%}$, and $\mathrm{F}_{\mathrm{B}}$. The overwintering rate of alfalfa is decreased with the increase of cutting times. Based on the DMY, nutritional quality and overwintering rate of alfalfa, the priority of the growth period suitable for alfalfa harvesting was: $\mathrm{F}_{\mathrm{B}}>\mathrm{F}_{5 \%}>\mathrm{F}_{15 \%}>$ $\mathrm{F}_{50 \%}$. In combination with the input cost, it is concluded that harvesting at $5 \%$ flowering stage of alfalfa seemed viable option to grow alfalfa under drip irrigation in the oasis area of Xinjiang, China. 
Liu et al. / Intl J Agric Biol, Vol 25, No 3, 2021

\section{Acknowledgements}

The research was supported by the National Natural Science Foundation of China (32001400, 31660693), the Fok Ying Tung Education Foundation of China (171099), the China Postdoctoral Science Foundation (2018T111120, 2017M613252), the Youth Innovation Talent Cultivation Program of Shihezi University (CXRC201605) and the China Agriculture Research System (CARS-34).

\section{Author Contributions}

Qianbing Zhang designed the study. Xuanshuai Liu and Yanliang Sun interpreted the results. Xuanshuai Liu, Yanliang Sun, Shengyi Li and Junwei Zhao performed the experiments. Xuanshuai Liu participated in writing the manuscript. Qianbing Zhang and Chunhui Ma supervised the study. All authors read and approved the final manuscript for publication.

\section{References}

Albrecht KA, WF Wedin, DR Buxton (1987). Cell-wall composition and digestibility of alfalfa stems and leaves. Crop Sci 27:735-741

Annicchiarico P (1993). Variation for dry matter yield, seed yield and other agronomic traits in Ladino white clover landraces and natural populations. Euphytica 71:131-141

Avci M, R Hatipoglu, S Çinar, N Kiliçalp (2017). Assessment of yield and quality characteristics of alfalfa (Medicago sativa $\mathrm{L}$.) cultivars with different fall dormancy rating. Legum Res 41:369-373

Dhont C, Y Castonguay, P Nadeau, G Bélanger, R Drapeau, FP Chalifour (2004). Untimely fall harvest affects dry matter yield and root organic reserves in field-grown alfalfa. Crop Sci 44:144-157

Fan W, G Ge, Y Liu, W Wang, L Liu, Y Jia (2018). Proteomics integrated with metabolomics: Analysis of the internal causes of nutrient changes in alfalfa at different growth stages. BMC Plant Biol 18; Article 78

Gramshaw D, K Lowe, D Lloyd (1993). Effect of cutting interval and winter dormancy on yield, persistence, nitrogen concentration, and root reserves of irrigated lucerne in the queensland subtropics. Aust $J$ Exp Agric 33:847-854

Gu YJ, CL Han, JW Fan, XP Shi, M Kong, XY Shi, KHM Siddique, YY Zhao, FM Li (2018). Alfalfa forage yield, soil water and $p$ availability in response to plastic film mulch and $\mathrm{P}$ fertilization in a semiarid environment. Field Crop Res 215:94-103

Han JG (2007). Grassland Science, $3^{\text {rd }}$ edn. Agricultural Press, Beijing, China

Hirwitz W, G Latimer (1995). Official methods of analysis of AOAC. Trends Food Sci Technol 6:382-382

Hoveland CS, RG Durham, JH Bouton (1996). Weed encroachment in established alfalfa as affected by cutting frequency. $J$ Prod Agric 9:323-402

Jia Y, FM Li, XL Wang, JZ Xu (2006). Dynamics of soil organic carbon and soil fertility affected by alfalfa productivity in a semiarid agroecosystem. Biogeochemistry 80:233-243
Kallenbach RL, CJ Nelson, JH Coutts (2002). Yield, quality, and persistence of grazing- and hay-type alfalfa under three harvest frequencies. Agron J 94:1094-1103

Karayilanli E, V Ayhan (2016). Investigation of feed value of alfalfa (Medicago sativa L.) harvested at different maturity stages. Legume Res 39:237-247

Lamb JF, GJ Hans-Joachim, H Riday (2012). Harvest impacts on alfalfa stem neutral detergent fiber concentration and digestibility and cell wall concentration and composition. Crop Sci 52:2402-2412

Lamb, JF, CC Sheaffer, DA Samac (2003). Population density and harvest maturity effects on leaf and stem yield in alfalfa. Agron J 95:635641

Lenssen AW, EL Sorensen, GL Posler (1990). Forage quality of genetically diverse alfalfa germplasms at four phenological growth stages. Euphytica 51:53-57

Martiniello P, R Paoletti, N Berardo (1997). Effect of phenological stages on dry matter and quality components in lucerne. Eur J Agron 6:79-87

Min D (2016). Effects of cutting interval between harvests on dry matter yield and nutritive value in alfalfa. Amer J Plant Sci 7:1226-1231

Moyer JR, J Fraser, LM Rode, AK Topinka (1999). Effects of growth-stagebased alfalfa harvest on weed encroachment and resultant quality. Can J Plant Sci 79:243-247

Rade S, B Dragoljub, D Dragan, S Vladeta, D Dragoslav (2012). Influence of plant density on yield components, yield and quality of seed and forage yields of alfalfa varieties. Rom Agric Res 29:245-254

Semel Y, N Schauer, U Roessner, D Zamir, AR Fernie (2007). Metabolite analysis for the comparison of irrigated and non-irrigated field grown tomato of varying genotype. Metabolomics 3:289-295

Sheaffer CC, DK Barnes, DD Warnes, WE Lueschen, DR Swanson (1992). Seeding-year cutting affects winter survival and its association with fall growth score in alfalfa. Crop Sci 32:225-231

Soest PVV, JB Robertson, BA Lewis (1991). Methods for dietary fiber, neutral detergent fiber, and nonstarch polysaccharides in relation to animal nutrition. J Dairy Sci 74:3583-3597

Staniak M, E Harasim (2018). Changes in nutritive value of alfalfa (Medicago $\times$ varia T. Martyn) and Festulolium (Festulolium braunii (K. Richt) A. Camus) under drought stress. J Agron Crop Sci 204:1-11

Testa G, F Gresta, SL Cosentino (2011). Dry matter and qualitative characteristics of alfalfa as affected by harvest times and soil water content. Eur J Agron 34:144-152

Trejo JAM, HWA Aguiluz, OR Jesús, RL Abel, PY Coronado (2010). Water use in alfalfa (Medicago sativa) with subsurface drip irrigation. Rev Mex Cienc Pec 1:145-156

Ventroni LM, JJ Volenec, CA Cangiano (2010). Fall dormancy and cutting frequency impact on alfalfa yield and yield components. Field Crop Res 119:252-259

Yari M, R Valizadeh, AA Naserian, A Jonker, P Yu (2012). Modeling nutrient availability of alfalfa hay harvested at three stages of maturity and in the afternoon and morning in dairy cows. Anim Feed Sci Technol 178:12-19

Zhang QB, JY Liu, XS Liu, SY Li, YL Sun, WH Lu, CH Ma (2020a). Optimizing water and phosphorus management to improve hay yield and water and phosphorus use efficiency of alfalfa under drip irrigation. Food Sci Nutr 8:2406-2418

Zhang QB, JY Liu, SY Li, XS Liu, WH Lu, XZ Wang, CH Ma (2020b). Reasonable coupling of water and phosphorus improves hay yield, and water and phosphorus use efficiency of alfalfa. Intl J Agric Biol 23:1061-1067

Zhao CY, ZD Feng, GD Chen (2004). Soil water balance simulation of alfalfa (Medicago sativa $\mathrm{L}$.) in the semiarid Chinese Loess Plateau. Agric Water Manage 69:101-114 